\title{
A SIMPÁTICA HISTÓRIA DE MELIM-MELOSO: A REINVENÇÃO DE MALAZARTE
}

\author{
Alessandra Bittencourt Flach
}

RESUMO: In Tutaméia, Guimarães Rosa makes a synthesis of what characterizes better his work as a whole: he explores the universe of types like the cowboy, the jagunço, the sinhá, the ordinary man from the sertão who has a lot to say, whether through his experiences narration, or through his particular worldview. To achieve that, the author makes use of a linguistic technique very peculiar to him. One of the 40 narratives presented in the book, "Melim-Meloso", is about the transcendence of this simple quotidian to a level of personal sublimation from the adventures of a wily type, following the model of the heroes from traditional oral short stories. The dialogue between Guimarães's character and Pedro Malazarte from the folk stories, more than a rescue of an ancestral theme, is a proof of how erudite culture has appropriated and reinvented the popular universe.

PALAVRAS-CHAVE: contos populares, herói, malandro

\author{
Da forma que vai o mundo \\ Só poderá triunfar \\ Aquele que tem astúcia \\ E não se deixa enganar. \\ No mar da vida se afoga \\ Quem nunca soube nadar. \\ (cantador Gomes de Barros, \\ apud PELOSO, 1996, p. 162)
}

Carlo Drummond de Andrade (2001a, p.14), na dificuldade de definir o "estilo", a "técnica" ou a "magia" de Guimarães Rosa, chega a duvidar da existência do escritor: "Ficamos sem saber o que João era e se João existiu de se pegar". Compartilhando do dilema poético de Drummond, não é difícil ficar em dúvida sobre se "João existiu de se pegar". Essa imaterialidade do autor não se dá por acaso. O mito Guimarães Rosa é como que a projeção dos seus textos, daí ser tão complicado defini-lo e, até mesmo, acreditar que tenha sido "gente de verdade", e não mais um de seus próprios personagens. Deixando de lado essas discussões metafísicas, resta a aventura de investir no universo literário que nos legou, repleto de enigmas e mistérios insolúveis.

Tutaméia, ou Terceiras estórias, é mais um desses livros inquietantes que Rosa nos oferece. São 40 histórias curtas, dispostas em uma ordem alfabética controversa, já que duas narrativas não se submetem a essa sequiência, mas a uma lógica imposta pelo autor, que "brinca" ao formar as iniciais de seu nome com a nova seqüência, "João Porém, o criador de perus", "Grande Gedeão" e "Reminisção". Não bastasse isso, as histórias são intercaladas por quatro pseudoprefácios, que pouco lembram a concepção que se tem de prefácio, tanto por sua localização no livro (em geral é um só, aparecendo antes do texto propriamente), quanto pelo conteúdo. Os de Tutaméia possuem amplo teor literário, sem nenhuma pretensão, portanto, de parecerem científicos ou esclarecedores do que quer seja, além daquilo que é possível através da ficção. Por todas essas peculiaridades é que talvez não se estranhe a maior delas: 
o título Terceiras estórias pressupõe serem a seqüência de "segundas estórias", que, na verdade, não existem. Como se percebe, a todo o momento, e de infinitas formas, o autor desconstrói as expectativas do leitor e cria uma armadilha para o crítico. Paulo Rónai, (2001a, p. 16), que muito refletiu sobre essas questões, conclui:

Rosa, para quem escrever tinha tanto de brincar quanto de rezar, antegozava-lhes [aos críticos] a perplexidade encontrando prazer em aumentá-la. Dir-se-ia até que neste volume [Tutaméia] quis adrede submetê-los a uma verdadeira corrida de obstáculos.

É por isso que cada nova história traz sempre o aspecto da surpresa e do desafio de tentar "ver o que está por trás". A habilidade do autor está em justamente ocultar a saída do labirinto, despistar. Nesse sentido, é uma Aridne às avessas, pois o fio que põe à disposição acaba por nos enredar ainda mais no mistério do narrado, até o ponto de ficarmos totalmente suscetíveis.

Aceitando a provocação de Rosa, pretende-se analisar o conto "Melim-Meloso", de Tutaméia, cujo personagem-título tem muitas aproximações com Pedro Malazarte, o herói dos contos orais tradicionais. Através da relação entre um e outro, pode-se perceber como a literatura "erudita", altamente simbólica e com recursos lingüísticos bastante desenvolvidos, apropria-se de um tema popular e, por extensão, do universo em que essa literatura ocorre, com seus códigos e modos de expressão. Ao mesmo tempo em que é possível perceber claramente a referência ao herói popular tradicional, o tratamento dado ao personagem de Rosa, bem como seu percurso como herói, são diferentes.

Basicamente, "Melim-Meloso" narra a história de um vaqueiro comum do sertão que possui aspirações modestas: ter a sua criação de animais e ir levando a vida sem grandes contratempos, de preferência trabalhando pouco e valendo-se da ingenuidade dos outros para obter algum lucro às suas custas. A voz do narrador é intercalada pelas quadras de João Barandão, que canta as aventuras do herói. Dois importantes episódios são narrados como que para ilustrar a vida errante e malandra do personagem: no primeiro deles, Melim-Meloso barganha com o "vendeirão" (ROSA, 2001a, p. 142) $)^{1}$ Bismarques o preço de um antiquado chapéu. Depois de desfazer do objeto, Melim-Meloso acaba comprando-o por um preço muito baixo, mas, como o vendedor acha que o chapéu ficou muito bem, decide aumentar o preço. No final das contas, o malandro consegue de volta o dinheiro que pagou (porque Bismarques acha que a nota é falsa), fica com o chapéu e ainda consegue que o outro lhe pague "um copázio de vinho" (p. 141). No outro episódio, que também tende a ilustrar o caráter ardiloso do herói, este, precisando vender seus sete cavalos para pagar uma dívida do padrasto, consegue, de forma sutil e engenhosa, convencer um dos compradores a restituir-lhe o animal. Para tanto, apela para a compaixão do desavisado homem, que cede às artimanhas melosas do herói, não só devolvendo-lhe o cavalo, como também dando-lhe mais algum dinheiro, com a esperança de reaver seus bens em um futuro próximo.

Como muitos dos contos tradicionais, a história não apresenta uma sequiência, uma sucessão cronológica dos fatos, mas o relato de vários episódios esparsos, que têm a função de exemplificar a conduta ou o caráter do protagonista. É o que diz André Jolles (1976, p. 192) ao definir o conto popular, em que o mesmo "salta de incidente em incidente para descrever todo um acontecimento que não se encerra em si mesmo de maneira determinada". Vários dados sugeridos pelo narrador não são aprofundados, como, por exemplo, qual o motivo real da desavença de Melim-Meloso com o padrasto, qual o desfecho das histórias amorosas mencionadas, o que sucedeu depois de conseguir o cavalo, como se sustentou. Ciente dessas aparentes lacunas e centrado em um foco bem determinado, o narrador contém a ansiedade do leitor: "São estas, aliás, para mais tarde, estórias de encompridar" (p. 142); "Porém, são para outra narração; convém que sejam. A vida de Melim-Meloso nunca se acaba” (p. 146).

Com base nas coletas feitas por Câmara Cascudo (Contos tradicionais do Brasil) e de Sílvio Romero (Contos populares do Brasil), tem-se acesso a muitos episódios que narram as aventuras de Pedro Malazarte e de outros heróis cujas malas artes decorrem de sua capacidade de enganar, todos os quais representados, de certa forma, em Melim-Meloso. Assim como a história deste, a vida de Malazarte "nunca se acaba", porque, no imaginário popular, que valoriza a esperteza e a iniciativa como formas de reação contra a opressão dos ricos, ele está sempre metido em algum logro. Como sobrevive (se não dura em emprego nenhum) e como vai terminar são aspectos que não interessam nesse contexto. Dessa forma, Cascudo (2003, p. 174-179) apresenta "Seis aventuras de Pedro Malazarte", não por acaso classificadas como "contos de exemplo". Trata-se de seis episódios que mostram como se dão as relações entre patrão e empregado e como o herói consegue vencer a exploração do trabalho a que é submetido, seja para vingar o irmão ou apenas para dar uma lição no carrasco, além de, jocosamente, denunciar como a ambição e a inveja podem levar a situações de ridículo, como no caso do homem que pensa ter comprado

\footnotetext{
${ }^{1}$ Como todas as citações do referido conto são tiradas da oitava edição de Tutaméia, publicada pela editora Nova Fronteira, em 2001, adiante serão designados apenas os números das páginas dos trechos.
} 
de Malazarte um urubu que fala e adivinha. O episódio registrado por Sílvio Romero dá conta de uma das facetas mais conhecidas deste herói popular: através da negociação e da troca, vai adquirindo bens que serão trocados por um benefício maior, neste caso, a admiração do rei. Também Romero (1985, p. 38-39) remete ao status episódico da narrativa, que fica evidente no próprio título: "Uma das de Pedro MalasArtes", que pressupõe a existência de aventuras anteriores, além de denotar o quanto as mesmas eram conhecidas do senso comum.

Malazarte vive das proezas que realiza. Sua principal arma é a esperteza. Dar-se bem na vida, para ele, não pressupõe enriquecer e estabilizar-se, firmar raízes. Por isso é que o trabalho não faz parte de seu universo, já que isso representaria submeter-se a um sistema em que o trabalho é para os pobres, oprimidos, enquanto a liberdade e os desmandos ficam a cargo de quem tem mais. Sua filosofia, segundo Peloso (1996, p. 157) é "viver de expedientes e realizar o seu objetivo mais importante: evitar o trabalho como se fosse uma peste". É o próprio estudioso que traz um exemplo bastante interessante sobre essa constante na vida do herói, extraído do folheto de cordel "As diabruras de Malasartes", de Expedito Sebastião da Silva:

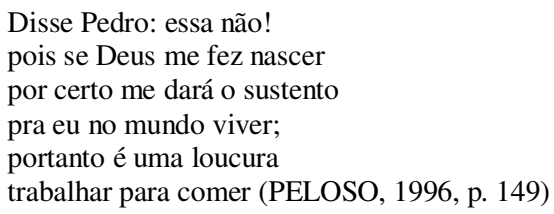

Guimarães Rosa se vale desse elemento para compor Melim-Meloso. Além de serem narradas aventuras isoladas, não é dito como o herói tem sustento, apenas que, esporadicamente, faz serviços de vaqueiro. Pela voz do cantador João Brandão, sabemos que "foi comprar um chapéu novo, / só não gosta de trabalho" (p. 141). No entanto, o narrador justifica: "Sombra de verdade, apenas. Ele trabalhava, em termos. E, o que sobre isso afirma, tira-se no bíblico e raia no evangélico" (p. 141). É o próprio MelimMeloso quem dá a sentença cabal: "Trabalho não é vergonha, é só uma maldição...” (p.141). Sua empresa será, portanto, fugir da maldição, assim como o fazem os heróis tradicionais.

Ainda que o foco aqui não seja uma abordagem das formas de expressão e significação da literatura oral tradicional, é importante entender como se dá essa construção para, adiante, analisar como Guimarães Rosa resgata-a no conto analisado. Especificamente em relação aos contos, Câmara Cascudo (2003, p. 13) define as seguintes características: antigüidade, anonimato, divulgação e persistência. Daí depreende-se a necessidade de uma tradição que legitime essa produção; uma intervenção coletiva que a recrie e adapte às situações e aos contextos; uma memória que, ao mesmo tempo em que conserva, difunde os motivos; e uma certa fixação de temas e formas, que, em certa medida, sofrem alterações, mas que conservam sua essência. A isso se soma a contribuição de André Jolles (1976, p. 195-196), ao fazer a distinção entre Forma Simples (produção oral) e Forma Artística (produção letrada)²:

Comecemos pela linguagem: na Forma Artística, ela esforça-se a tal ponto por ser sólida, peculiar e única, que é impossível imaginá-la, por fim, a não ser como linguagem própria de um indivíduo bafejado pelo dom excelente de poder alcançar [...] a coesão suprema [...] o cunho sólido, peculiar e único da personalidade de seu autor. [...]

Na Forma Simples, pelo contrário, a linguagem permanece fluida, aberta, dotada de mobilidade e de capacidade de renovação constante. Costuma-se dizer que qualquer um pode contar um conto, uma saga ou uma legenda "com suas próprias palavras". [...]

O que acabamos de mostrar a propósito da linguagem pode ser estendido a tudo o que se encontre em ambas as formas: personagens, lugares, incidentes.

A literatura oral tradicional, ou Forma Simples, constitui-se por elementos diferentes daqueles empregados na literatura erudita, ou Forma Artística, não estando em jogo um juízo de valor sobre uma ou outra. Se, como diz Jolles, a primeira tem maior mobilidade e está sujeita a uma renovação constante, é porque sua produção não é fixada, ou seja, não está subordinada ao registro da escrita, que, por um lado, atua como recurso de conservação, mas, por outro, refreia essa mobilidade. Por ninguém se apropriar dessas histórias exigindo para si o reconhecimento da autoria e pelo fato de o conceito de originalidade não fazer parte desse contexto, podem viajar entre culturas, serem adaptadas e empregadas sem qualquer problema da ordem de "fidelidade" ou "deturpação" do texto original, pois este é uma abstração. As histórias existem enquanto existirem quem as transmita, do jeito que se quiser contar. No entanto: "Cada vez que a linguagem participa na constituição de tal forma, cada vez que intervém nesta para vinculá-la a uma ordem dada ou alterar-lhe a ordem e remodelá-la, podemos falar então de Formas Literárias" (JOLLES, 1976, p. 290).

\footnotetext{
2 Ao fazer tal distinção, em nenhum momento Jolles atribui maior valor a esta em detrimento daquela, nem os sentidos de "simples" e "artística" denotam, respectivamente, banalização e elaboração, uma vez que ambas são expressões de arte, cada uma a seu modo.
} 
Nas produções orais, o sentido é construído não só pelo que é dito, mas principalmente pela maneira como é dito. Assim, voz, gesto, som, "clima", espectador, tudo é parte da performance narrativa (ZUMTHOR, 1993). É fato que, ao serem transcritas para o papel, essas histórias perdem muito de sua vivacidade, se se considerar, por exemplo, as coletas de Cascudo e Romero. A sensação que se tem ao ler muitas delas é que "falta alguma coisa". Essa ausência é um resquício da performance. No entanto, através dessas e de outras marcas da oralidade (linguagem, forma, estrutura), é possível resgatar parte do contexto em que foram produzidas e, a partir disso, buscar sua contemporaneidade, ou seja, aquilo que elas têm a dizer ainda hoje.

A "moral da história" é expressa claramente, seja através do comportamento maniqueísta dos personagens, seja ela dita ao final da narração. Não há espaço para análise psicológica, impasses, divagações, filosofias ou ruminações. As lições são diretas, sintéticas, pragmáticas, mas nem por isso menos significativas. Por ser uma produção coletiva, as relações que se estabelecem no conto e a trajetória do herói adquirem proporções quase sociológicas, na medida em que refletem o cotidiano dessas pessoas para as quais e pelas quais as histórias são contadas, havendo uma identificação automática entre o narrado e o vivido, uma espécie de sublimação através do ato de ouvir e contar histórias.

A literatura que provém da cultura letrada é escrita, o que oferece ao autor recursos lingüísticos que não estão disponíveis na oralidade. Assim, ele pode imprimir sua marca pessoal. O leitor pode interromper a leitura, recuar nas páginas, desistir de ler. Também não há uma identificação obrigatória entre quem escreve e quem lê. Mesmo pressupondo-se um leitor virtual, o autor deixa de ter domínio sobre o público, não pode prever reações, até por que estas são tantas quantos forem os leitores. $\mathrm{O}$ conteúdo narrado adquire expressões mais singulares, pois não há um compromisso em atender a um público específico, assim como as experiências narradas são menos arquetípicas, universalizam-se a partir de vivências pessoais. O herói não está a serviço de um código coletivo, tem autonomia, tem liberdade para fracassar, para não corresponder às expectativas, não precisa ser modelo. O papel do narrador é valorizado, pois não é imparcial, pode opinar, discutir e tomar partido.

De forma mais específica, em relação ao herói popular, pode-se perceber que é categorizado em duas amplas categorias: aquele que realiza suas peripécias através de um objeto mágico (varinha, ajuda sobrenatural, objeto encantado) e aquele que vence pelos próprios méritos (inteligência, esperteza, coragem, força). Claro está que Malazarte enquadra-se neste segundo grupo. Para Roberto DaMatta (1997, p. 274): "não há dúvida de que estamos diante de um "herói sem nenhum caráter", ou melhor, de um personagem cuja marca é saber converter todas as desvantagens em vantagens, sinal de todo bom malandro e de toda e qualquer boa malandragem".

Parece contraditório que o engano e o roubo sejam "virtudes" de um herói. No entanto, quando Malazarte os pratica, não os faz por simples maldade, por falsidade, mas por necessidade, por honra, para dar uma lição em alguém. Ao lograr, utiliza os mesmos recursos da vítima, exceto pelo fato de que o motivo que o impulsiona ao ato é mais "nobre", porque atende a uma ética particular. O roubo, segundo Cascudo (1984, p. 26), desde que praticado dentro das condições consideradas oportunas, não tinha um caráter negativo, como se a vítima, sabedora de que está suscetível a esses atos, não tivesse outra alternativa além de tomar cuidado e, se isso não fosse o bastante, então teria mesmo de se conformar. Principalmente o abigeato, roubo de gado, era um acontecimento natural e sem recriminação no contexto rural, cuja herança, segundo o pesquisador, é moura e árabe.

Na vida pastoril de outrora, séculos XVIII e XIX, quando os fios de arame farpado não dividiam as pastagens e a gadaria era criada solta e livre, confusa, indeterminada, difícil a identificação da propriedade, animais sem ferros e marcas de posse, [...] o abigeato não era crime, punível e reprovável. Seria forma hábil de aquisição oportuna, gratuita e natural.

Amadeu Amaral (1976, p. 332-333) recolheu uma história de Malazarte que ilustra bem esse comentário de Cascudo. Segue um trecho:

Malasartes arranjou um dia uma pequena boiada, e andava com ela até que anoiteceu. Resolveu então pedir pousada numa fazenda, e também licença para soltar a boiada no pasto.

- Não há perigo de se misturarem os meus bois com os seus, dizia ele ao fazendeiro. Os meus estão todos bem marcados.

O fazendeiro concordou. Malasartes soltou os bois no pasto e foi dormir. De manhã muito cedo saltou da cama e tratou de reunir a boiada.

O campeiro da fazenda acompanhou-o. Pedro pegava aqui um touro, ali uma vaca, acolá um vitelo, dos seus e dos da fazenda, arrebatando tudo à vontade.

De quando em quando o campeiro observava:

- Então como é isso? Esse boi é do patrão, eu o conheço muito...

- Está enganado, respondia Malasartes. Eu não disse que os meus estavam todos muito bem marcados?

- Mas eu não vejo marca nenhuma. Que marca é essa? 
- Olhe aqui, explicou Malasartes, agarrando a cauda de um boi. A minha marca é um O. Veja... E lá se foi com os bois do fazendeiro.

Um dado histórico, a "gadaria criada solta e livre", é adaptado ao conto, em que, mais uma vez, o herói tenta tirar vantagem da sua esperteza. Sutilmente, apropria-se dos bois do fazendeiro através de um argumento convincente, ainda que embasado em um engodo. A vítima fica passiva diante das "evidências". O fazendeiro percebe que seu gado está sendo levado, mas parece não ter coragem (ou até direito) de reclamar. Assim, o logro é, de certa forma, respeitado, não pelo ato de roubar em si, mas pela audácia e esperteza com que isso é feito. Não é à toa que o nome do personagem é Malazarte (ou suas variações, Malasartes, Malas-Artes, Maas-Artes). Ao mesmo tempo em que carrega a sina de um herói mal-aventurado, à margem, suas trapaças são qualificadas como arte, reforçando essa admiração por sua maneira de agir e de sobreviver. Essa constante do personagem folclórico é aproveitada por Guimarães Rosa na construção de Melim-Meloso. Daí que suas ardilosas manobras são admiradas pelas próprias vítimas, que são lesadas, mas, em vez de indignação, reagem com admiração. Mais que isso: até um leitor mais desavisado é capaz de não perceber seus delitos, uma vez que a simpatia e a vivacidade do protagonista, endossadas pelos comentários do narrador, adquirem a maior força dentro da história.

Feitas essas considerações sobre o herói da literatura oral tradicional, já se pode voltar para "a simpática história de Melim-Meloso, filho das serras, intransitivo, deslizado, evadido do azar" (p. 140). O primeiro aspecto a se deter é a questão da influência do folclore na obra de Rosa. Mesmo reconhecendo o diálogo entre o texto escrito e os temas populares, deve-se ter claro que se trata de expressões diferentes. Ao buscar na tradição popular um tema amplamente divulgado, Guimarães Rosa não pretende tãosomente reproduzi-lo. Há um trabalho de criação pessoal bastante complexo, que não precisa, e nem deveria ser, "fiel" às raízes. Basta, para tanto, lembrar das definições de Forma Simples e Forma Artística, de Jolles. Assim, a função que o herói exerce, o efeito de suas atitudes e a maneira como isso é construído são próprias a cada "gênero", a tal ponto que o texto de Rosa não exige que se tenha conhecimento do herói popular para fazer sentido. Além disso, as transformações e reelaborações são tantas que a base popular da qual partiu o autor acaba por se dissipar dentro do texto, como lembra Kathrin Rosenfield (2006, p. 81): "Rosa sempre fabrica suas obras com materiais historicamente prémoldados, fazendo desaparecer os rastros das suas fontes de inspiração graças a uma poderosa sensibilidade e... um ardiloso manejo de variadas técnicas".

Inicia-se o conto com uma referência à forma consagrada do "Era uma vez...", "Num lugar muito distante...", marcando, ao mesmo tempo, a indeterminação do tempo e a legitimidade do depoimento, garantida pelo distanciamento temporal. No entanto, a maneira como o autor o faz, além de situar a história em um tempo impreciso, coloca em xeque sua existência, sugerindo até uma possível inexistência do que será narrado: "Nos tempos que não sei, pode ser até que ele venha a existir" (p. 140). Isso permite ao narrador que não tenha qualquer compromisso com algo que possa ter acontecido. Cabe ao leitor acreditar ou não no que será exposto. Tal posicionamento destoa do papel que exerce o narrador dos contos populares, que se coloca como testemunha do narrado, dando provas concretas, tentando convencer o espectador através de uma autoridade que lhe é conferida pelo papel que exerce como mediador entre o mundo cotidiano, vulgar, e o universo mágico e sagrado das histórias.

Em relação ao protagonista, as malas artes de Melim-Meloso são muito parecidas com as do herói tradicional, mas, no conto erudito, se dão através de um discurso mais "meloso", mais "melindroso", para brincar com o nome do personagem. Nos contos tradicionais, como já referido, as atitudes do personagem são exemplares, paradigmáticas. É por meio delas que conhecemos o caráter do herói e suas virtudes. Em "Melim-Meloso", isso se constrói sob três perspectivas: também pelas atitudes do personagem, pelos comentários do narrador e pelos versos do cantador. O que se percebe é que, em certos momentos, essas vozes são dissonantes entre si. O cantador exulta o herói e suas façanhas; o narrador expõe o seu drama, pois precisa desfazer-se de seus bens para pagar a dívida de um padrasto com o qual não tinha afinidade, ao mesmo tempo em que pretende mostrar "a outra face da lenda" (p. 143); e as atitudes e falas do herói (estas últimas poucas e um tanto filosóficas em certos momentos) aproximam-se do aspecto da burla e do engodo que são constantes nas peripécias de Malazarte.

O cantador, em cada uma das 12 quadras em que se manifesta ao longo do conto, está sempre a descrever o herói, a caracterizá-lo, principalmente sua capacidade de reverter uma situação de desvantagem a seu favor. Para ele, não há tristeza, tudo é vivido intensamente, tudo é revertido em seu benefício.

Melim-Meloso

amontado no corcel:

porque é Melim-Meloso, 
bebe fel e sente $\mathrm{mel}^{3}$. (p. 143)

Por conta disso, exalta suas façanhas, faz dele um mito, uma lenda. Destaca seu caráter aventureiro e itinerante. Nos versos a seguir, reforça a fama de conquistador, com uma noiva em cada lugar.

\section{Melim-Meloso \\ amontado no murzelo: \\ uma nôiva em Santa-Rita, \\ outra nôiva no Curvelo. (p. 142)}

Essa atitude de exaltação é muito recorrente nas trovas, nos A. B. C., nos desafios de repentistas. No entanto, outro aspecto deste cantador ficcional é bastante peculiar à obra: suas frases enigmáticas e reticentes, por vezes até melancólicas:

\section{Encontrei Melim-Meloso}

fazendo idéias de bois:

o que ele imaginava em antes

vira a certeza depois. (p. 140)

Poucos são os personagens sertanejos de Rosa que não se encontram, em certos momentos, "fazendo idéias de bois" ". Difícil é precisar exatamente do que se trata. Esse ruminar das idéias é expresso através da aproximação/identificação com algo que é bastante caro ao vaqueiro, o boi, seu companheiro das longas jornadas, motivo de sua sobrevivência. A "sabedoria" dos bois parece estar relacionada à capacidade de matutar, de ponderar as coisas, de ter a paciência de esperar o momento certo de as coisas acontecerem. Sete das 12 quadras têm uma estrutura que se repete: "Melim-Meloso amontado no seu baio..." (p. 141), "Melim-Meloso amontado no pedrês..." (p. 143), assim mencionando os sete cavalos que o herói será obrigado a vender para saldar as dívidas do padrasto, cada um dos quais de uma "qualidade" diferente: baio, pedrês, murzelo, alazão, quartau, corcel e castanho, nomes bastante recorrentes no contexto dos vaqueiros. Se, como dissemos, o cantador tem a função de definir o herói através de seus versos, o fato de reiterar a figura de Melim-Meloso montado no cavalo reforça o quanto o animal era importante para ele, quase como uma extensão sua.

O cavalo, além de companhia, é o instrumento de trabalho do vaqueiro, é ele que o acompanha nas andanças de uma fazenda para outra, por caminhos longos e hostis ${ }^{5}$. "Melim-Meloso possuía somente seus sete cavalos, comprados, um a um, com seus economizados" (p. 144). Sendo seu único bem, desfazer-se deles, além de impedi-lo de trabalhar, implica perder sua dignidade, garantida pelo acúmulo de alguma posse. Por extensão, perde parte de sua identidade. Cabe questionar, então, se vale o sacrifício de desfazer-se dos animais em benefício de uma dívida que não era sua, mas de um defunto, do qual fazia questão de nem querer saber. Talvez do ponto de vista de alguém que não conhece ou não participa deste código sertanejo que Rosa tão bem representa, Melim-Meloso agiu mal em saldar as dívidas. Ele desperdiçou uma boa oportunidade de vingar-se do padrasto, mesmo após sua morte, pois poderia deixar difundir-se a fama de caloteiro que certamente se espalharia em relação ao nome do falecido. Contudo, o código da honra é hereditário. Se um familiar (mesmo não sendo de sangue) adquire uma dívida, esta não morre com ele, permanece. Ignorá-la é o mesmo que atestar a própria má-fé, tornar-se caloteiro.

No início do conto, como já referido, é narrado um acontecimento em que Malazarte desfaz de um chapéu que pretende comprar ${ }^{6}$, em uma disputa com Bismarques, o vendedor avarento e, ao mesmo

\footnotetext{
${ }^{3}$ Neste último verso, Guimarães Rosa retoma um elemento bastante recorrente nos contos tradicionais. No entanto, inverte o sentido da frase. Trata-se do conselho do pai viúvo à sua filha quando esta lhe pede que se case com a "bondosa" vizinha: "Agora ela lhe dá mel, minha filha, amanhã lhe dará fel” (“A menina enterrada viva”, CASCUDO, 2003, p. 302). O pai tinha razão. Assim que casou, a mulher se transformou em uma madrasta cruel e vingativa. Melim-Meloso, por sua vez, transformando limão em limonada, como diz o ditado, faz das agruras (fel) alegrias (mel).

${ }^{4}$ Como nesses trechos, em que homem e animal se fundem: "José Mariano caminhava embora, no andar bamboleado, cabeça baixa, ruminando seu cansaço. Se abria e unia, com ele, - vaca negra - a noite, vaca" ("Entremeio com o vaqueiro Mariano", ROSA, 2001b, p. 127); "Olha, o que eu entendo das pessoas, foi com o traquejo dos bois que eu aprendi..." ("O burrinho pedrês", ROSA, 1984 , p. 48).

${ }^{5}$ Tão ao gosto do autor, poderia se fazer uma análise dos aspectos simbólicos e metafísicos contidos na figura do cavalo e do cavaleiro. SIGANOS (1998, p. 123) chama a atenção para o fato de que o cavalo pode assumir a função de condutor iniciático, "psicopompo" (condutor de almas; na mitologia, um dos epítetos de Hermes). Poderia se considerar que Melim-Meloso passa, através das experiências narradas, por um ritual de iniciação e provação, interno e profundo, mas semelhante às provações pelas quais passam os heróis dos contos tradicionais. Os versos "Errando sempre, para adiante, / um acerta sem saber" (p. 143) sugerem essa conotação da errância, do percurso continuado, da aprendizagem. Para detalhes sobre a questão da influência metafísica em Guimarães Rosa, ver UTÉZA (1994).

"Em "Seis aventuras de Pedro Malazarte" (CASCUDO, 2003, p. 177), o herói vale-se do mesmo tipo de negociação. Ao perceber que um comboio se aproximava, enterra as brasas que eram usadas para preparar sua comida e coloca uma panelinha sobre elas. Acaba convencendo os passantes de que a panela fervia sem fogo. Vendo o interesse em comprá-la, Malazarte fez-se de rogado,
} 
tempo, ingênuo, pois não percebe as artimanhas que Melim-Meloso emprega para a) levar o chapéu sem pagar nada, b) beber de graça, c) dar uma lição no comerciante que tenta "vender gato por lebre" e, por fim, d) sair-se ileso de qualquer acusação de logro e, se possível, ainda ser admirado por suas engenhosidades.

Para conseguir isso, emprega sua sedutora lábia, enredando o vendedor em sua própria armadilha. Este quis lhe vender um produto fora de moda, "encalhado". Ora aumenta, ora diminui o preço, conforme o interesse do comprador. Acaba sendo pago com uma nota falsa, a qual, de forma "condescendente", Melim-Meloso aceita de volta. Para selar o negócio duvidoso, este convida o outro para uma bebida. Só depois Bismarques vai se dar conta de que, mais uma vez, foi enganado, pois aquele não cumprira a etiqueta do "quem convida paga". Mesmo assim, "Restou desenxabido; não mal-alegrado de todo" (p. 141). Por que não se indigna? Porque sabe que também aplicara o mesmo golpe, mas perdeu no duelo para um mais habilidoso, que precisa ser reconhecido.

No caso dos cavalos, precisa vender pelos motivos já referidos. No entanto, consegue reaver um deles, além de levar um dinheiro com isso. Após a venda, o herói decide ir embora, humilhado. Não bastasse isso, os "sujeitos que lhe tinham comprado os cavalos, compareceram na saída, para o afligir, cada qual montado no agora seu" (p. 145). Melim-Meloso, matutamente, faz os cavalos "eqüivocados" (p. 145) correrem atrás de uma égua no cio. Com o impacto, todos caem da montaria, em uma cena bizarra, menos um: João Vero ${ }^{7}$, a vítima. Depois de elogiá-lo, Melim-Meloso apela para sua sensibilidade: diz que irá para outros campos ganhar dinheiro e voltar para readquirir seus cavalos. Sensibilizado, João entregalhe o cavalo, com o acordo de ser restituído quando aquele voltar. Para completar, o herói pede mais um dinheiro, para arredondar o montante da dívida. Vai-se. É através do narrador que fica sugerido que não voltará: chega à sugestiva "Fazenda Atravessada" (p. 146), onde "se deram várias coisas, ele com elas" (p. 146). Ainda que empenhasse sua palavra, esse contrato se constituiu sobre uma base de troça, pois, não se pode esquecer, João Vero tem sua parcela de punição por ter zombado da sorte do herói.

Mais uma vez, suas trapaças são legitimadas por uma necessidade. Em vez de desconfiar, ameaçar ou recomendar que retorne logo, Pedro Vero "se riu, por dentro e por fora" (p. 146). Talvez não tenha se deixado enganar, talvez tenha percebido a maquinação de Melim-Meloso, mas decidiu compactuar e exercer seu papel de vítima, para ajudar o homem e para fazer persistir a lenda.

No fim das contas, nem tudo é alegria, como em muitos versos se cantou ("o sofrer vigia o gozo / mas o gozo não tem fim" (p. 144), já que Melim-Meloso termina com um saldo negativo, perdendo seis dos sete cavalos, mal restando um para deixar a região e tentar a sorte em outro lugar. Cria-se, de certo modo, um paradoxo, já que o cantador enfoca as alegrias, e o narrador faz ver que o herói, além de sua condição difícil de sobrevivência, é filho da Serra do Sõe: "Lá, ressoam distâncias; e a alegria é pouca; é devagarinho, feito um gole" (p. 144). Melim-Meloso vive um certo determinismo do meio, mas sua heroicidade (e nesse aspecto aproxima-se muito de Malazarte) está em fazer desses pequenos entraves um incentivo para buscar alternativas. Acima de tudo, trata-se de um idealista, de alguém que está sempre recomeçando depois de um tropeço, e não exagera o cantador quando diz: "O que ganho, nunca perco, / o que perco é sempre ganho" (p. 143). Reconhecendo não ser possível viver à margem do sofrimento e da provação, reage a eles tentando burlá-los.

Por um lado, Melim-Meloso constitui-se herói paradigmático, tal qual Malazarte, na medida em que se torna, segundo DaMatta (1997, p. 276), "um relativizador das leis, regulamentos, códigos e moralidades que sufocam o indivíduo sem berço". Por outro lado, pelo fato de o conto ser uma produção intelectual autoral, escrita, feita para indivíduos, não pra grupos, o herói não precisa, necessariamente, estar a serviço da coletividade. Por conta disso, é que adquire uma singularidade de representação, que é capaz de fazer o leitor identificar-se com ele, já que suas experiências são possíveis de acontecer a qualquer um. Ele transcende a condição de tipo, própria dos contos tradicionais, em que os personagens são caracterizados como uma coisa ou outra, não tendo, portanto, conflitos, dilemas ou contradições. Melim-Meloso, ainda que na superfície apresentado como herói popular, sublimador de sua classe, encerra em si uma série de complexidades que jamais seriam encontradas em um herói pertencente ao imaginário da literatura oral tradicional. Se, por exemplo, na coleta de Cascudo (2003), Malazarte sai pelo mundo movido por uma necessidade de vingar a exploração sofrida pelo irmão, também é por uma questão familiar que o personagem de Rosa vive sua maior experiência. No entanto, o vínculo com o padrasto não se dá por laços afetivos, mas por uma questão de honra, da qual não é possível safar-se.

dizendo que era algo muito valioso e raro e que não estava pensando em vender. Mas, tendo insistido tanto, um dos homens acaba comprando a tal panelinha. Só foi perceber o logro quando já estava muito longe.

${ }^{7}$ Mais uma jogada de Rosa: João Vero (verdade), iludido por uma mentira. 
É interessante perceber como Melim-Meloso, tão esperto e tão cheio de galhofas, resolve o conflito com o padrasto. Aliás, outro elemento popular nos contos tradicionais é a figura da madrasta como antagonista, figura má e invejosa, sempre impondo um obstáculo à vida do herói. Rosa sagazmente inverte o gênero.

Melim-Meloso tinha pena de não ser órfão também de padrasto, com quem descombinava; porque o padrasto era prático de bronco, na desalegria, não avistava o sutil de viver, principalmente. Vai um dia, Melim-Meloso não agüentou mais: - Faço de conta que este padrasto não existe, de jeito nenhum... - ele entendeu de obrar, com doçuras. Isto é: não via mais, nem de frente nem em mente, a pessoa existente do padrasto, para bem ou para mal. (p. 146)

Ora, fazer de conta que algo não existe é semelhante à criança pequena que acredita que não existe aquilo que não pode ver. O compromisso em herdar as dívidas também pode ser interpretado como uma espécie de mea culpa. É certo que o conflito com o padrasto, tão diferente dele, vivendo de "desalegria", quando Melim-Meloso "bebe fel e sente mel" (p. 143), o incomodava, a ponto de tentar iludir a si mesmo de que isso não era real. Note-se como tanto o narrador quanto o personagem apresentam uma visão quase infantil em relação à questão. A maneira como estruturam o pensamento é bastante semelhante àquilo que Rosa faz na composição de seus ricos personagens infantis, como, por exemplo, no caso do Miguilim, de "Campo Geral", novela de Manuezão e Miguilim (2001d), uma maneira de perceber e conceituar as coisas bastante específicas, que, de certa forma, redunda em uma visão de mundo semelhante aos personagens sertanejos de Rosa. Para ilustrar, veja-se o tratamento dado por Melim-Meloso ao sentido da vida: "A vida são dívidas. A vida são coisas muito compridas" (p. 145). Da mesma forma, no trecho a seguir, da Canção de Siruiz, de Grande sertão: veredas, percebe-se como o célebre Riobaldo definia as questões mais complexas através de imagens e metáforas bastante simples.

Vida é sorte perigosa

passada na obrigação.

Toda noite é rio-abaixo

Todo dia é escuridão. (ROSA, 2001c, p. 334)

Um e outro, ainda que tendo como paradigma experiências bem diferentes, combinam em pensamento ao considerar a vida como algo difícil de ser enfrentado, imprevisto, muitas vezes penoso. Cada um a seu modo, não se deixam embrutecer por ela, como ocorre com o padrasto de Melim-Meloso. Esse é o segredo. Sobre essa forma de representação do pensamento, diz Kathrin Rosenfield (2006, p. 48):

Os vaqueiros são os protagonistas prediletos, porque a personagem simples e rústica, firmemente enraizada nas atividades concretas e práticas, é mais livre da nociva introspecção, tem a mente menos sobrecarregada de noções ou conceitos e vê o mundo sem as sutilezas estudadas da consciência histórica e psicológica.

Talvez o aspecto mais manifesto da apropriação do conto tradicional e de sua reelaboração com Forma Artística seja o tratamento dado ao narrador. Aparentemente, ele se aproxima bastante do contador de histórias, pois faz suspense, conduz a história, sabe de todos os detalhes, induz o leitor, faz uso das estruturas já referidas de indeterminar o tempo, refere-se a episódios que não serão narrados, a fim de aguçar a curiosidade do espectador. No entanto, sua função principal é desconstruir o mito do herói coletivo a que se refere o cantador, o qual atua como uma espécie de senso comum, e, assim, humanizar e pessoalizar o personagem. Dessa forma, enquanto o tom das intervenções do cantador é sempre de celebração e euforia, como no caso das façanhas amorosas,

Melim-Meloso

amontado no murzelo:

uma nôiva em Santa-Rita,

outra nôiva no Curvelo.

Melim-Meloso

amontado no alazão:

- Veio ver minha senhora,

disto é que eu não gosto, não. (p. 142)

o narrador interpreta esses feitos e situa-os no contexto em que ocorrem:

A nôiva em Santa-Rita, Quirulina, era só por uma amizade emprestada. Maria Roméia, a nôiva no Curvelo, a ele ensinava apenas certas formas de ingratidão. E a mulher do Nhô Tampado notavase como a feia das feias. (p. 142)

Ao mesmo tempo, parece haver um descompasso entre aquilo que o narrador expõe sobre a essência do personagem e o que este pensa, reforçando, dessa forma, sua complexidade e ambigüidade, comuns a qualquer indivíduo submerso nos dilemas da vida. Enquanto Melim-Meloso diz "Sou homem 
de todas as palavras!", o narrador acrescenta: "Mas guardava segredos; e aproveitava qualquer silêncio" (p. 143). Guardar segredos e aproveitar qualquer silêncio não podem fazer parte de um personagem que se pretende plano, transparente, como Malazarte. São elementos constituintes de um herói altamente complexo, ambivalente, que só é possível existir através da elaboração acurada de um autor, que não precisa ser conciso e direto, que desperta no leitor não apenas a catarse da identificação imediata, mas o faz ruminar "idéias de bois" (p. 140).

A universalização do conto se dá, então, não tanto por retomar um herói arquetípico, mas por fazer que as experiências de um tipo como Melim-Meloso, num lugar determinado, sejam compreendidas e vividas, em qualquer lugar ou tempo, por qualquer pessoa que se identifique com elas. Um herói previsível e exemplar como Malazarte, ainda que atendendo a uma necessidade coletiva de heróis, talvez não dê conta de sublimar todos os nossos complexos dramas pessoais, talvez isso nem tenha mais sentido. Rosa joga com as vozes do conto para compor um herói ambivalente e, em certa medida, fragmentado, pois nem o narrador, nem o cantador, nem as ações do personagem dão conta sozinhos de defini-lo. Cabe ao leitor juntar os pedaços e tentar montar o quebra-cabeça. O beber nas águas da literatura oral tradicional pode ter sido um despiste para encobrir, sob uma aparente simplicidade, a riqueza de um personagem como esse. Muitos são os recursos de que o autor se vale: "Porém são para outra narração; convém que sejam. A vida de Melim-Meloso nunca se acaba” (p. 146).

\section{BIBLIOGRAFIA}

AMARAL, Amadeu. Pedro Malasartes. In: AMARAL, Amadeu. Tradições populares. 2.ed. São Paulo: Hucitec, 1976. p. 303-344.

ANDRADE, Carlos Drummond de. Um chamado João. In: ROSA, João Guimarães. Tutaméia (Terceiras estórias). 8.ed. Rio de Janeiro: Nova Fronteira, 2001a.

CASCUDO, Luís da Câmara. Mouros, franceses e judeus. São Paulo: Perspectiva, 1984. (Debates)

CASCUDO, Luís da Câmara. Contos tradicionais do Brasil. 12.ed. São Paulo: Global, 2003.

CASCUDO, Luís da Câmara. Vaqueiros e cantadores. São Paulo: Global, 2005.

DaMATTA, Roberto. Carnavais, malandros e heróis: para uma sociologia do dilema brasileiro. 6.ed. Rio de Janeiro: Rocco, 1997.

JOLLES, André. Formas simples. São Paulo: Cultrix, 1976.

PELOSO, Silvano. O ciclo do anti-herói: antimodelos na cultura popular. In: PELOSO, Silvano. O canto e a memória: história e utopia no imaginário popular brasileiro. São Paulo: Ática, 1996. p. 147-179.

ROMERO, Sílvio. Contos populares do Brasil. Belo Horizonte: Itatiaia; São Paulo: Edusp, 1985.

RÓNAI, Paulo. Os prefácios de Tutaméia. In: ROSA, João Guimarães. Tutaméia (Terceiras estórias). 8.ed. Rio de Janeiro: Nova Fronteira, 2001a.

ROSA, João Guimarães. Sagarana. Rio de Janeiro: Record, 1984.

ROSA, João Guimarães. Tutaméia (Terceiras estórias). 8.ed. Rio de Janeiro: Nova Fronteira, 2001a.

ROSA, João Guimarães. Estas estórias. 5.ed. Rio de Janeiro: Nova Fronteira, 2001b.

ROSA, João Guimarães. Grande sertão: veredas. 19.ed. Rio de Janeiro: Nova Fronteira, 2001c.

ROSA, João Guimarães. Manuelzão e Miguilim (Corpo de baile). 11.ed. Rio de Janeiro: Nova Fronteira, 2001d.

ROSENFIELD, Kathrin Holzermayr. Desenveredando o Rosa: a obra de J. G. Rosa e outros ensaios roseanos. Rio de Janeiro: Topbooks, 2006.

SIGANOS, André. Bestiário mítico. In: BRUNEL, Pierre (Org.). Dicionário de mitos literários. 2.ed. Rio de Janeiro: José Olympio, 1998. p.117-137.

UTÉZA, Francis. Metafísica do Grande Sertão. São Paulo: Edusp, 1994.

ZUMTHOR, Paul. A letra e a voz. São Paulo: Cia das Letras, 1993. 